\title{
Metabolic activity of fresh-cut 'Pérola' pineapple as affected by cut shape and temperature
}

\author{
Lucimara R. Antoniolli ${ }^{1}$, Benedito C. Benedettii ${ }^{*}$, José M.M. Sigrist ${ }^{3}$, Men de Sá M. Souza Filho ${ }^{4}$ and Ricardo E. Alves ${ }^{4}$
}

${ }^{1}$ Embrapa Uva e Vinho, CP 130, CEP 95700-000, Bento Gonçalves-RS; ${ }^{*}$ Universidade Estadual de Campinas, Faculdade de Engenharia Agrícola, CP 6011, CEP 13083-970, Campinas-SP; '3nstituto de Tecnologia de Alimentos, CP 139, CEP 13073-001, Campinas-SP; ${ }^{4}$ Embrapa Agroindústria Tropical, CP 13761, CEP 60511-110, Fortaleza-CE. *Corresponding author: benedeti@agr.unicamp.br

Received: 04 July 2006; Returned for revision: 16 September 2006; Accepted: 13 November 2006

The effects of cut shape and temperature on the respiratory activity and ethylene synthesis of fresh-cut 'Pérola' pineapple were investigated. Two experiments were carried out. In the first, slices and chunks were placed in air-tight packages kept at 4 or $10^{\circ} \mathrm{C}$. Gas samples were taken every $2 \mathrm{~h}$ during $12 \mathrm{~h}$ and analysed by gas chromatography. In the second experiment, peeled fruits, slices and chunks were placed in air-tight glass jars connected to a flowboard installed in a cold room at $5 \pm 1{ }^{\circ} \mathrm{C}$. This system provided a continuous flow of humid and cold air during $14 \mathrm{~d}$. Respiration rate was determined every $2 \mathrm{~h}$, during the first $12 \mathrm{~h}$, then daily for $10 \mathrm{~d}$ and on days 12 and 14 . Ethylene synthesis was not detected during $12 \mathrm{~h}$ of evaluation. The lower respiration rates that occurred when fruits were stored at $4{ }^{\circ} \mathrm{C}$ indicate that this condition provides greater shelf life for the fresh-cut product. The initial respiration rate of slices and chunks stored at $5^{\circ} \mathrm{C}$ doubled as compared with peeled fruits under the same conditions. The respiratory behaviour of slices and chunks was very similar during $14 \mathrm{~d}$ of cold storage, with respiration rates between 1.96 and $4.10 \mathrm{mg} \mathrm{CO}_{2} \mathrm{~kg}^{-1} \mathrm{~h}^{-1}$.

Key words: Ananas comosus, ethylene, minimal processing, respiration rate

\section{Atividade metabólica de abacaxi 'Pérola' minimamente processado decorrente do formato de corte e da temperatura:} Procurou-se avaliar a influência do formato de corte e da temperatura sobre a atividade respiratória e a síntese de etileno em abacaxis 'Pérola' minimamente processados. Dois experimentos foram realizados. No primeiro, fatias e cubos foram acondicionados em embalagens herméticas mantidas a 4 ou a $10^{\circ} \mathrm{C}$. Alíquotas gasosas foram retiradas a cada $2 \mathrm{~h}$, durante $12 \mathrm{~h}$, e analisadas por meio de cromatografia gasosa. No segundo experimento, frutos inteiros descascados, fatias e cubos foram acondicionados em frascos de vidro herméticos conectados a um fluxcentro instalado em câmara refrigerada a $5 \pm 1^{\circ} \mathrm{C}$. Tal sistema garantiu o fornecimento de um fluxo contínuo de ar umidificado e frio durante $14 \mathrm{~d}$. $\mathrm{O}$ monitoramento da taxa respiratória foi realizado em intervalos de $2 \mathrm{~h}$, nas primeiras $12 \mathrm{~h}$, então diariamente por $10 \mathrm{~d}$, e nos dias 12 e 14. Não foi detectada síntese de etileno no período de $12 \mathrm{~h}$ em que foram realizadas as análises de cromatografia gasosa. As menores taxas respiratórias ocorreram quando os frutos foram acondicionados a $4^{\circ} \mathrm{C}$, indicando que essa condição proporciona maior vida útil ao produto minimamente processado. A taxa respiratória inicial dos frutos cortados em fatias e cubos, acondicionados a $5^{\circ} \mathrm{C}$, correspondeu ao dobro da observada nos frutos inteiros descascados mantidos na mesma condição. $\mathrm{O}$ comportamento respiratório dos frutos minimamente processados em fatias e cubos foi muito semelhante, durante os $14 \mathrm{~d}$ de armazenamento refrigerado, com taxas respiratórias oscilando entre 1,96 e 4,10 $\mathrm{mg}$ $\mathrm{CO}_{2} \mathrm{~kg}^{-1} \mathrm{~h}^{-1}$.

Palavras-chave: Ananas comosus, atividade respiratória, etileno, processamento mínimo 
The pineapple is a composite, non-climacteric fruit that shows moderate to low rates of respiration and ethylene production (Dull et al., 1967). Wounding during the preparation of fresh-cut fruits and vegetables, that involves operations of peeling and size reduction, leads to some modifications of their metabolism, such as alterations in the respiration and ethylene production rates. The increment in the respiration rate is probably due to increased surface area exposed to the atmosphere after cutting that allows a more rapid diffusion of oxygen to the internal cells and to increased metabolic activity of injured cells (Zagory, 1999). The respiration rate of pineapples harvested at the mature green stage and cut in chunks varied between 2.0 and $2.5 \mathrm{~mL} \mathrm{CO}_{2} \mathrm{~kg}^{-1} \mathrm{~h}^{-1}$ when kept at $5^{\circ} \mathrm{C}$, and between 3.5 and $8.0 \mathrm{~mL} \mathrm{CO}_{2} \mathrm{~kg}^{-1}$ $\mathrm{h}^{-1}$ when kept at $10^{\circ} \mathrm{C}$. Fruits with a yellow skin showed respiration rates between 5.5 and 7.0, and between 13.0 and $16.0 \mathrm{~mL} \mathrm{CO}_{2} \mathrm{~kg}^{-1} \mathrm{~h}^{-1}$ when stored at $5^{\circ} \mathrm{C}$ and $10^{\circ} \mathrm{C}$, respectively. Slices with $10 \mathrm{~mm}$ of thickness showed respiration rates between 0.5 and $1.0,1.3$ and 4.0 and between 4.0 and $16.0 \mathrm{~mL} \mathrm{CO}_{2} \mathrm{~kg}^{-1} \mathrm{~h}^{-1}$ at $0^{\circ} \mathrm{C}, 5^{\circ} \mathrm{C}$ and $10^{\circ} \mathrm{C}$, respectively (Gorny, 2003). The purpose of this research was to evaluate the effects of the cut shape and temperature on the respiratory activity and ethylene synthesis of fresh-cut 'Pérola' pineapple. The results of this work can be used in developing appropriate packaging to extend the conservation of fresh-cut pineapple.

Two independent experiments were carried out. In the first one, pineapples (Ananas comosus (L.) Merril. 'Pérola') were obtained from an experimental grower in Paraipaba (Ceará State, Northeast Brazil) and transported to "Embrapa Agroindústria Tropical". The fruits were selected according to the size and the skin colour (fruits completely green and fruits with the centre region yellow corresponding to stages 1 and 2 of the Pineapple Classification Standards (Centro de Qualidade em Horticultura, 2003). The crowns were cut at about $30 \mathrm{~mm}$ from the fruit apical region. After that, fruits were washed with water and neutral detergent, and disinfected with a solution of $\mathrm{NaOCl}\left(200 \mathrm{mg} \mathrm{L}^{-1}\right)$ for $2 \mathrm{~min}$. Fruits where placed in washed and disinfected $\left(200 \mathrm{mg} \mathrm{L}^{-1} \mathrm{NaOCl}\right.$ solution) plastic boxes and kept at $12 \pm 1^{\circ} \mathrm{C}$ for approximately $24 \mathrm{~h}$. In order to obtain fresh-cut pineapple slices and chunks the fruits were mechanically peeled and manually sliced. The slices were cut approximately 10 mm thick and their cores removed. The chunks were obtained by cutting the slices in four equal sections. The processing was carried out under refrigerated conditions, with temperatures between 12 and $15^{\circ} \mathrm{C}$. The equipment and utensils were disinfected with $200 \mathrm{mg} \mathrm{L}^{-1} \mathrm{NaOCl}$ solution to prevent cross contamination. Disposable gloves, masks and surgical caps were used for the same purpose. Slices and chunks were placed in air-tight packages $(1.5 \mathrm{~L})$. The packages were fitted with a rubber septum, which allowed for headspace gas sampling. They were kept at $4^{\circ} \mathrm{C}$ or $10^{\circ} \mathrm{C}$ for $12 \mathrm{~h}$. Gas samples were taken every $2 \mathrm{~h}$ during $12 \mathrm{~h}$ and injected in a gas chromatograph (model CG 86.10, Dani, São Paulo, Brazil) fitted with a TCD detector for $\mathrm{CO}_{2}$ and a FID detector for ethylene. A Porapak N column of $4.0 \mathrm{~m}$ in length and $1 / 8$ " diameter was used and operated at a constant temperature of $60^{\circ} \mathrm{C}$, with hydrogen as carrier gas at a flow rate of $30 \mathrm{~mL} \mathrm{~min}^{-1}$. Carbon dioxide and ethylene were quantified after calibration with standards of $5 \% \mathrm{CO}_{2}$ and $10 \mu \mathrm{L} \mathrm{L}^{-1}$ ethylene, respectively. The experiment was arranged in a completely randomised design with three replications, in which the interaction between cut shape (slices and chunks), temperature $\left(4^{\circ} \mathrm{C}\right.$ and $\left.10^{\circ} \mathrm{C}\right)$ and experimental period $(0,2,4,6,8,10$ and $12 \mathrm{~h})$ was studied. Each package with four slices (without cores) or 16 chunks $(0.330 \mathrm{~kg})$ was considered as a replicate. Data were submitted to an analysis of variance (ANOVA) and means compared by Tukey's test at $P<0.05$.

In a second experiment, pineapples from a commercial grower in Miranorte (Tocantins State, Central-West Brazil) were pre-selected and transported to the "Instituto de Tecnologia de Alimentos" (Campinas, São Paulo State, Brazil), where they were submitted to the same process of selection, washing and disinfection previously described. In order to obtain fresh-cut pineapple, the fruits were manually peeled and sliced. Peeled fruits, slices and chunks were sanitised in a solution of $\mathrm{NaOCl}\left(20 \mathrm{mg} \mathrm{L}^{-1}\right)$ at $10^{\circ} \mathrm{C}$ for $30 \mathrm{~s}$. The excess liquid was drained for $2 \mathrm{~min}$ and the freshcut fruits placed in air-tight glass jars $(3.6 \mathrm{~L})$ which were connected to a flowboard (a device to mix and control the flow of gases; Claypool and Keefer, 1942; Calbo, 1989), installed in a cold room at $5 \pm 1^{\circ} \mathrm{C}$. The flowboard system guaranteed the continuous flow of humid and cold air during $14 \mathrm{~d}$. Before entering the flowboard, the air passed through solutions of $20 \% \mathrm{Ca}(\mathrm{OH})_{2}$ and $20 \% \mathrm{KMnO}_{4}$, to free it of carbon dioxide and ethylene, respectively. 
Gas samples $(1 \mathrm{~mL})$ were taken from each jar with a syringe and injected in a gas chromatograph (model Star 3400, Varian, Walnut Creek, California, USA) fitted with a Hyesep N column of $1.0 \mathrm{~m}$ in length and a TCD detector for $\mathrm{CO}_{2}$, operated at $70^{\circ} \mathrm{C}, 60^{\circ} \mathrm{C}$ and $140^{\circ} \mathrm{C}$, for injector, column and detector, respectively. Hydrogen was used as carrier gas at a flow rate of $26 \mathrm{~mL} \mathrm{~min}{ }^{-1}$. Carbon dioxide was quantified after calibration with standards of $500 \mu \mathrm{L} \mathrm{L}^{-1}$ and $10 \% \mathrm{CO}_{2}$. The respiration rates $\left(\mathrm{mg} \mathrm{CO}_{2} \mathrm{~kg}^{-1} \mathrm{~h}^{-1}\right)$ were evaluated every $2 \mathrm{~h}$ during the first $12 \mathrm{~h}$, then daily for $10 \mathrm{~d}$ and on days 12 and 14 . The experiment was arranged in a completely randomised design with three replications, the interaction between cut shape (peeled fruits, slices and chunks) and experimental period $(2,4,6,8,10,12 \mathrm{~h}$ and 0,1 , $2,3,4,5,6,7,8,9,10,12$ and 14 d) was studied. Each jar with one peeled fruit $(0.950 \mathrm{~kg})$ or five slices without cores $(0.350$ $\mathrm{kg})$ or 20 chunks $(0.350 \mathrm{~kg})$ was considered as a replicate. Data were submitted to an analysis of variance (ANOVA) and means compared by Tukey's test at $P<0.05$.

Ethylene synthesis was not detected in the initial period of $12 \mathrm{~h}$ after minimal processing (data not shown). This result is in accordance with that found by Latifah et al. (2000), who did not detect ethylene production in fresh-cut 'Josapine' pineapple during $2 \mathrm{~d}$ of storage at $25^{\circ} \mathrm{C}$ and $7 \mathrm{~d}$ at $10^{\circ} \mathrm{C}$. However, Marrero and Kader (2001) observed a sharp rise in respiration rate followed by an increase in ethylene production that indicated the end of commercial life of fresh-cut 'Champaka' pineapple. As reported by those authors, the continuation of storage beyond this point led to the appearance of off-flavours, odours and microbial spoilage. Despite ethylene biosynthesis being activated by physical wounding, not all plant tissues respond to this stress with significant increases in the production of this plant hormone (Salveit, 1999). Cantwell and Suslow (1999) observed that fresh-cut ripe cantaloupe, kiwi and strawberry kept at $20^{\circ} \mathrm{C}$, showed increases in ethylene production of 10,8 and 4 times, respectively, when compared to the respective intact fruits. On the other hand, fresh-cut bananas kept under the same conditions did not present alterations in ethylene synthesis when compared to the intact fruits. Ethylene production of fresh-cut cantaloupe and strawberry kept at $2^{\circ} \mathrm{C}$ were identical to the respective intact fruits. Additionally, Marrero and Kader (2006) found that wounding induced a permanent increase in ethylene production in fresh-cut 'Smooth Cayenne' pineapple at $10^{\circ} \mathrm{C}$, but not at 0 and $2.2^{\circ} \mathrm{C}$.
There was less $\mathrm{CO}_{2}$ accumulation in the packages kept at $4^{\circ} \mathrm{C}$ than in those kept at $10^{\circ} \mathrm{C}$, independent of the cut shape, which implies that the fresh-cut pineapples stored in this condition showed lower respiratory activity (Figure 1A). Similarly, Sarzi et al. (2002) observed greater $\mathrm{CO}_{2}$ concentration in the packages with fresh-cut 'Pérola' pineapple stored at $9^{\circ} \mathrm{C}$, when compared to those kept at 6 and $3^{\circ} \mathrm{C}$. There was an increase in the $\mathrm{CO}_{2}$ concentration in the packages with time. The effects of temperature were observed from the $6^{\text {th }} \mathrm{h}$ after minimal processing, when the fresh-cut fruits kept at $4^{\circ} \mathrm{C}$ showed lower respiratory activity than that ones kept at $10^{\circ} \mathrm{C}$, resulting in a $\mathrm{CO}_{2}$ concentration statistically lower in the packages that contained them. This behaviour remained until the end of the $12 \mathrm{~h}$ evaluation period (Figure 1B). Considering that the storage temperature of intact fruits was $12 \pm 1^{\circ} \mathrm{C}$ and the temperature of the processing room oscillated between $12-15^{\circ} \mathrm{C}$, it could be assumed that the temperature of the fresh-cut pineapple pulp was around $12^{\circ} \mathrm{C}$ at time 0 . Therefore, the effect of storage temperature was observed only when the temperature of the fruit pulp reached the desired one $\left(4^{\circ} \mathrm{C}\right.$ or $10^{\circ} \mathrm{C}$ ). Watada et al. (1996) observed that the respiration rates of fresh-cut fruits and vegetables increased with temperature. According to Schlimme (1995) the storage of fresh-cut fruits and vegetables at temperatures as high as $10^{\circ} \mathrm{C}$ can hasten the natural deterioration process, considering that $\mathrm{Q}_{10}$ of biological reactions ranges from three to four and possibly as high as seven within this temperature level.

In the second experiment, no significant interaction was observed between cut shape and time during the first $12 \mathrm{~h}$ in which respiration rate was evaluated. Independently of time, the peeled pineapple showed a lower respiration rate $\left(1.96 \mathrm{mg} \mathrm{CO}_{2} \mathrm{~kg}^{-1} \mathrm{~h}^{-1}\right)$ than slices and chunks with 3.91 and $4.28 \mathrm{mg} \mathrm{CO}_{2} \mathrm{~kg}^{-1} \mathrm{~h}^{-1}$, respectively (Figure 2A). The respiration rate showed a slight increase up to the $6^{\text {th }} \mathrm{h}$ after minimal processing, followed by a decline and reaching $3.00 \mathrm{mg} \mathrm{CO}_{2} \mathrm{~kg}^{-1} \mathrm{~h}^{-1}$ at $12 \mathrm{~h}$ after processing (Figure $2 \mathrm{~B}$ ). The results of the second experiment showed that the initial respiration rate of fresh-cut pineapples slices and chunks was, approximately, double that observed in the peeled fruits, probably due to the higher stress level caused by wounding. The respiratory behaviour of slices and chunks was very similar, with respiration rates between 1.96 and $4.10 \mathrm{mg} \mathrm{CO}_{2} \mathrm{~kg}^{-1} \mathrm{~h}^{-1}$ during the $14 \mathrm{~d}$ of 


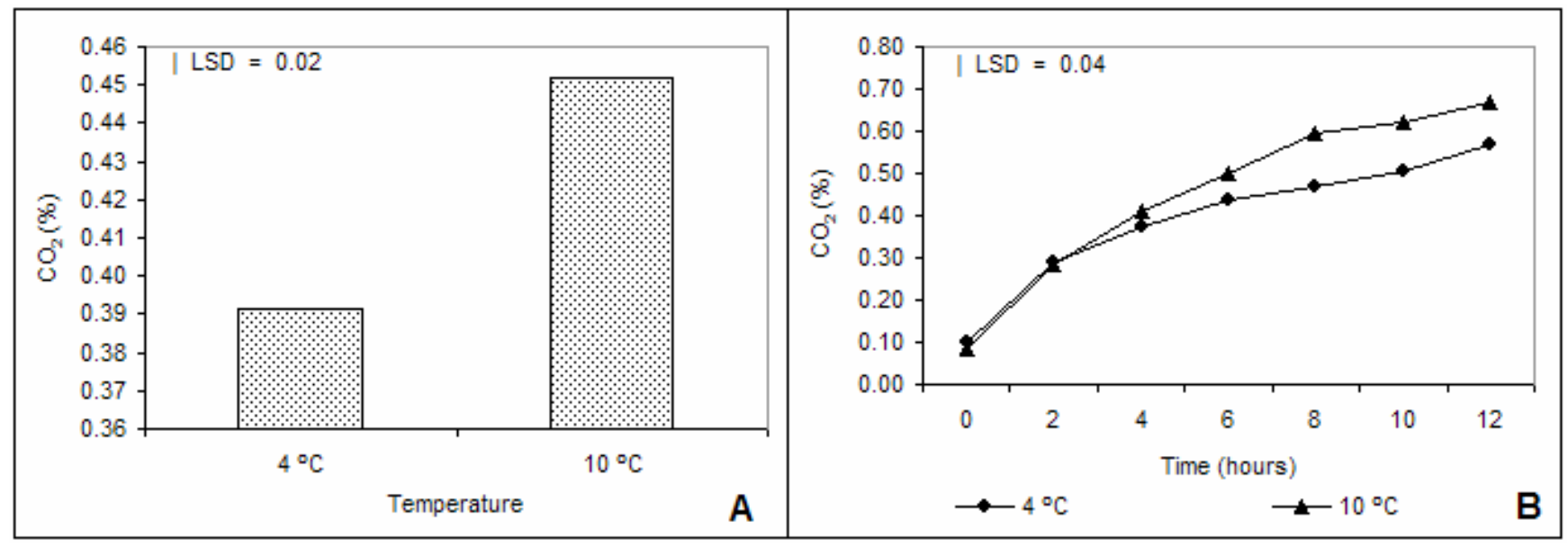

Figure 1. Carbon dioxide accumulation in the packages of fresh-cut 'Pérola' pineapple kept at $4^{\circ} \mathrm{C}$ and $10^{\circ} \mathrm{C}(\mathrm{A})$ and changes in the first $12 \mathrm{~h}$ after minimal processing (B). Vertical bars show the least significant differences (LSD) at the 0.05 level.

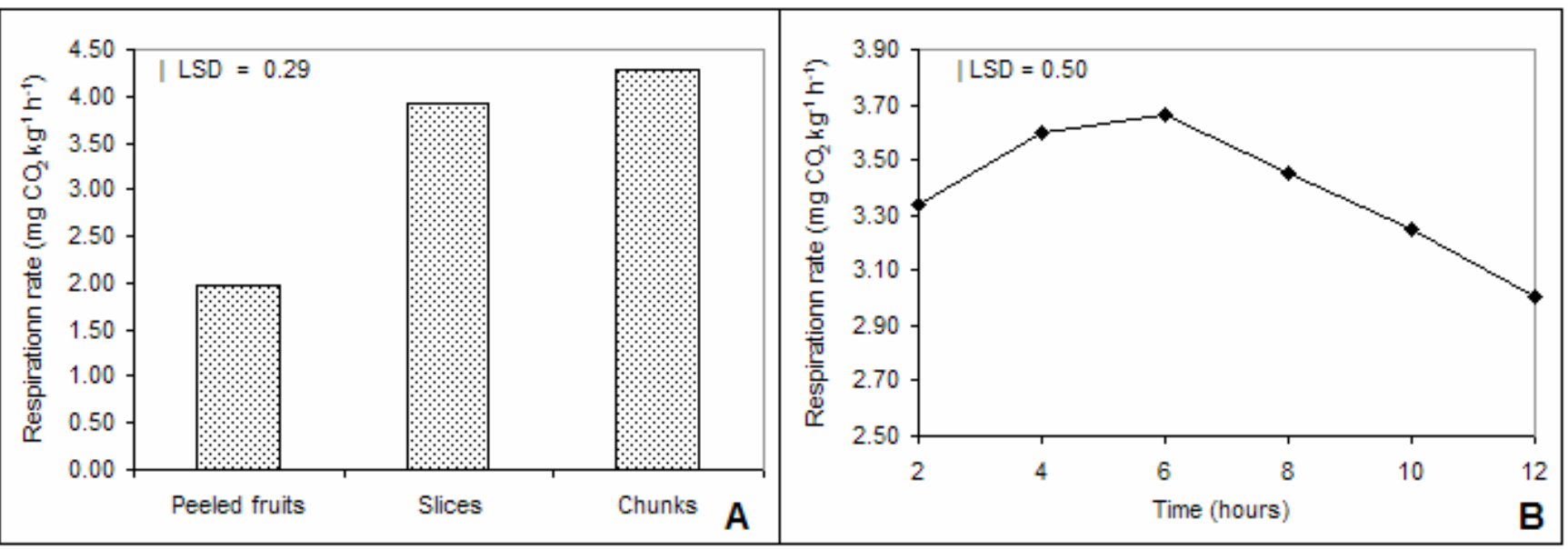

Figure 2. Respiration rates of peeled 'Pérola' pineapple and fresh-cut in slices and chunks (A) and changes in the first $12 \mathrm{~h}$ of storage at $5 \pm 1^{\circ} \mathrm{C}(\mathbf{B})$. Statistics as in Figure 1.

refrigerated storage (Figure 3). Similarly, higher respiration rates were observed in fresh-cut 'Pérola' pineapple (Sarzi et al., 2002) and in fresh-cut 'Smooth Cayenne' pineapple (Budu et al., 2001) when compared with the respiration rates of peeled fruits. Watada et al. (1996) verified that respiration rates of peeled and sliced ripe kiwifruit were double that observed in the intact fruits; however, they did not observe a similar effect in ripe bananas. There was a decline in the respiration rate of peeled fruit up to the $2^{\text {nd }}$ day after processing. After that there was a continuous increase (Figure 3). The respiration rate of these fruits reached values close to the ones observed in slices and chunks on the $9^{\text {th }}$ day, with no statistical difference between them. This behaviour remained until the $12^{\text {th }}$ day. At the end of the storage period, the peeled fruits showed a higher respiration rate than those of fresh-cut pineapples (Figure 3).

In this work, the following conclusions were reached: (i) ethylene synthesis was not detected during the initial period of $12 \mathrm{~h}$ after minimal processing; (ii) lower respiration rates occurred when fruits were stored at $4^{\circ} \mathrm{C}$; (iii) the initial respiration rate of slices and chunks stored 


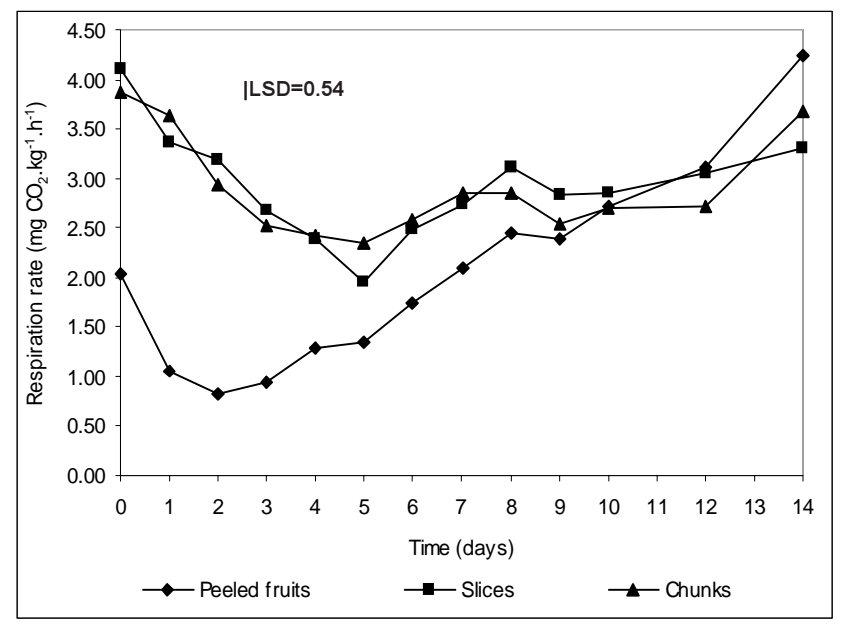

Figure 3. Respiration rates of peeled 'Pérola' pineapple and fresh-cut in slices and chunks during $14 \mathrm{~d}$ of storage at $5 \pm 1^{\circ} \mathrm{C}$. Statistics as in Figure 1.

at $5^{\circ} \mathrm{C}$ was double that observed in the peeled fruits under the same condition; and (iv) the respiratory behavior of slices and chunks was very similar during 14 $\mathrm{d}$ of cold storage.

Acknowledgements: This research received financial support from the Fundação de Amparo à Pesquisa do Estado de São Paulo (FAPESP) and Prodetab / Banco Mundial. The authors thank Claísa A. Silva de Freitas and Débora Belo Alves for their technical contributions to this research.

\section{REFERENCES}

Budu AS, Joyce DC, Aked J, Thompson AK (2001) Respiration of intact and minimally processed pineapple fruit. Trop. Sci. 41:119-125.

Calbo AG (1989) Adaptação de um fluxcentro para estudos de trocas gasosas e um método de aferição de capilares. Pesq. Agropec. Bras. 24:733-739.

Cantwell M, Suslow T (1999) Fresh-cut fruits and vegetables: Aspects of physiology, preparation and handling that affect quality. In: 5th Annual Workshop on Fresh-Cut Products: Maintaining Quality and Safety. University of California, Davis, pp.1-22. (Section 4b).

Centro de Qualidade em Horticultura (2003). Programa Brasileiro para a Modernização da Horticultura - Normas de Classificação do Abacaxi. CQH, São Paulo (Documentos, 24).

Claypool LL, Keefer RM (1942) A colorimetric method for $\mathrm{CO}_{2}$ determination. Proc. Am. Soc. Hort. Sci. 40:177-186.

Dull GG, Young RE, Biale JB (1967) Respiratory patterns in fruit of pineapple, Ananas comosus, detached at different stages of development. Physiol. Plant. 20:1059-1065.

Gorny JR (2003) Packaging design for fresh-cut produce. International Fresh-Cut Producer Association, Alexandria, VA, USA.

Latifah MN, Abdullah H, Selamat M, Habsah M, Talib Y, Rahman KM, Jabir H (2000) Shelf life of minimally processed pineapple. J. Trop. Agric. Food. Sci. 28:7985.

Marrero A, Kader AA (2001) Factors affecting the postcutting life and quality of minimally processed pineapple. Acta Hort. 553:705-706.

Marrero A, Kader AA (2006) Optimal temperature and modified atmosphere for keeping quality of fresh-cut pineapples. Postharvest Biol. Technol. 39:163-168.

Saltveit ME (1999) Fresh-cut product biology. In: 5th Annual Workshop on Fresh-Cut Products: Maintaining Quality and Safety. University of California, Davis, pp.110. (Section 4a).

Sarzi B, Durigan JF, Rossi Júnior OD (2002) Temperatura e tipo de preparo na conservação de produto minimamente processado de abacaxi 'Pérola'. Rev. Bras. Frutic. 24:376380.

Schlimme DV (1995) Marketing lightly processed fruits and vegetables. HortScience 30:15-17.

Watada AE, Ko NP, Minott DA (1996) Factors affecting quality of fresh-cut horticultural products. Postharvest Biol. Technol. 9:115-125.

Zagory D (1999) Controlled and modified atmospheres. I General aspects of film technology and selection. In: 5th Annual Workshop on Fresh-Cut Products: Maintaining Quality and Safety. University of California, Davis, pp.1-3. (Section 7a). 